\title{
Extração de DNA para análise da amelogenina em amostras fixadas em formalina, incluídas em parafina e armazenadas por 1 e 5 anos no Departamento de Patologia da Universidade Federal de São Paulo
}

\author{
Extraction of DNA for analysis of amelogenin in samples \\ fixed in formalin, embedded in paraffin stored for 1 and 5 \\ years in the Department of Pathology - Federal University of \\ Sao Paulo
}

Funabashi, KS'; Iwamura, ESM ${ }^{1}$

\begin{abstract}
Funabashi, KS; Iwamura, ESM. Extração de DNA para análise da amelogenina em amostras fixadas em formalina, incluídas em parafina e armazenadas por 1 e 5 anos no Departamento de Patologia da Universidade Federal de São Paulo. Saúde, Ética \& Justiça. 2013;18(Ed. Especial):39-44.
\end{abstract}

\begin{abstract}
RESUMO: O uso da biologia molecular em amostras fixadas em formalina e incluídas em parafina (FFPE) vem crescendo, e a melhoria nos métodos de obtenção do DNA para sua análise é necessária. O objetivo deste estudo foi avaliar o DNA extraído de blocos de tecidos FFPE (fígado, baço e cérebro não tumorais), obtidos de necropsia, 8 a 24 horas post mortem, utilizando três métodos de extração de DNA (kit comercial, fenolclorofórmio e Salting-Out). Foram realizadas as PCRs dos genes da $\beta$-actina (136pb), amelogenina humana (AMEL 212-218pb) e STRs (100-400pb) para avaliar a eficácia do método de extração de DNA e determinar o sexo dos indivíduos. Foram utilizados 28 casos arquivados (1 e 5 anos) e 12 recentes, sendo analisadas 10 amostras de cada um dos tecidos. O kit comercial apresentou maior grau de pureza, resultados reprodutíveis e consistentes na amplificação por PCR nos genes da $\beta$-actina e AMEL e na análise por STR. Este estudo fornece uma compreensão dos desafios envolvendo amostras FFPE, e esclareceu novas estratégias para análises moleculares neste tipo de material.
\end{abstract}

PALAVRAS-CHAVE: PCR, STR; Autópsia; Patologia Molecular; FFPE.

\footnotetext{
Este trabalho resumido faz parte da DIssertação de Mestrado de Karina S.Funabashi. O artigo completo foi publicado: Funabashi et al. DNA extraction and molecular analysis of non-tumoral liver, spleen, and brain from autopsy samples: The effect of formalin fixation and paraffin embedding. Pathology, Research and Practice, v. 208, p. 584-591, 2012. doi: 10.1016/j.prp.2012.07.001.

1. Departamento de Patologia - Escola Paulista de Medicina, Universidade Federal de São Paulo - EPM/UNIFESP, São Paulo, SP

Endereço para correspondência: Departamento de Patologia- EPM/ UNIFESP. Rua Botucatu, 740. CEP 04023-062 - São Paulo, SP Brasil. Email: ksfunabashi@gmail.com
} 


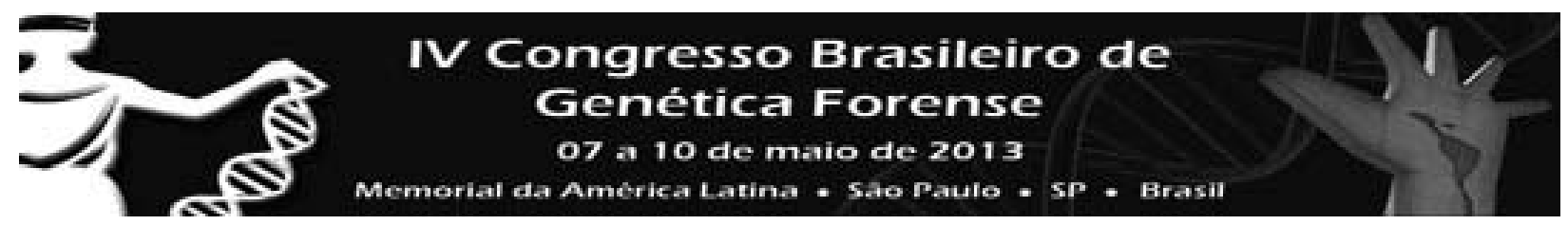

\section{INTRODUÇÃO}

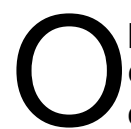
processo de fixação em formalina e inclusão em parafina (FFPE) é considerado um método padrão de preservação de amostras biológicas por longos períodos. Este tipo de amostra é importante para diagnósticos médicos, ${ }^{1} e s t u d o s$ genéticos retrospectivos e epidemiológicos ${ }^{2}$, uso em investigação forense ${ }^{3-6}$ e são uma excelente fonte de DNA, ${ }^{7,8}$ embora sua recuperação para analise molecular ainda seja um desafio ${ }^{9}$.

O processamento de amostras parafinadas, apesar de ser padronizado, pode variar de acordo com cada rotina laboratorial ${ }^{10}$. Extensas ligações cruzadas entre proteínas nos tecidos $e$ fragmentação do DNA podem ser encontradas e, portanto, uma baixa qualidade de DNA pode ser obtida ${ }^{11}$

Existem diversos protocolos descritos para a extração de DNA em diferentes amostras. Entretanto, a extração de DNA em tecidos parafinados requer protocolos especiais, pois este tipo de material geralmente é escasso, degradado, e pode conter substâncias que inibem os procedimentos moleculares ${ }^{12}$. Desta maneira, é importante compreender e analisar cada etapa do procedimento de amostras parafinadas: desde a fixação até a análise molecular.

\section{OBJETIVO}

O objetivo deste estudo foi avaliar o DNA extraído de fragmentos não tumorais de fígado, baço e cérebro normais FFPE obtidos de necropsia de 8 a 24 horas post mortem, recentes, arquivados por 1 e 5 anos e em amostras congeladas, utilizando três métodos de extração de DNA. Além disso, a amplificação do gene da $\beta$-actina (136pb) e da amelogenina humana $(212 \mathrm{pb}-218 \mathrm{pb} / 106 \mathrm{pb}-112 \mathrm{pb})$ foi realizada com o propósito de, respectivamente, avaliar a eficácia do método de extração de DNA e determinar o sexo dos indivíduos neste tipo de amostra.

\section{MATERIAIS E MÉTODO}

\section{Amostras FFPE: recentes, armazenadas por $1 \mathrm{e}$ por 5 anos}

Nosso estudo envolveu 12 casos de necropsia recentes, dos quais foram coletadas amostras normais de fígado $(n=10)$, baço $(n=10)$ e cérebro $(n=10)$ em duplicata, sendo que uma parte FFPE de acordo com a rotina de patologia e o outro grupo foi congelado para ser utilizado como controle. Além disso, utilizamos blocos de parafina contendo fragmentos normais de fígado, baço e cérebro ( $\mathrm{n}=10$ cada tecido) armazenados por 1 (13 casos) e 5 anos (15 casos), todos obtidos de exames de necropsia, de 8 a 24 horas post mortem.

\section{Extração de DNA}

Das amostras congeladas, foram utilizadas aproximadamente $25 \mathrm{mg}$; dos blocos de parafina, foram utilizados 2 cortes de $10 \mu \mathrm{m}$ com $1 \mathrm{~cm}^{2}$ de tecido. Para a remoção da parafina, foram realizadas 2 lavagens com xilol e etanol a $100 \%$. Métodos de extração: a) Fenol-clorofórmio (25:24:1): foram adicionadas às amostras $500 \mu \mathrm{l}$ de tampão de digestão (Tris- $\mathrm{HCl} 1 \mathrm{mM}$ pH 8.0; EDTA $0.5 \mathrm{mM}$ e Tween $20,0.5 \%$ ) com $20 \mathrm{mg} / \mathrm{ml}$ de proteinase K. As amostras foram incubadas com o tampão em overnight a $56^{\circ} \mathrm{C}$. Em seguida, $500 \mu \mathrm{l}$ de fenol-clorofórmio foram adicionados. As amostras foram centrifugadas por 2 minutos a 16000xg e o sobrenadante foi transferido para um novo tubo de $1,5 \mathrm{ml}$. O fenol-clorofórmio foi adicionado novamente no volume de $500 \mu \mathrm{l}$ e os tubos foram centrifugados a $16000 \mathrm{xg}$ por 4 minutos. O DNA foi precipitado com $4 \mu \mathrm{l}$ de acetato de sódio a $3 \mathrm{M} \mathrm{pH} 4.8$ e $1 \mathrm{ml}$ de etanol $100 \%$ por 2 horas e ressuspendido em $80 \mu \mathrm{l}$ de solução TE (Tris- $\mathrm{HCl} 1 \mathrm{mM}$ e EDTA $0.5 \mathrm{mM} \mathrm{pH} \mathrm{8);} \mathrm{b)} \mathrm{Kit} \mathrm{comercial} \mathrm{(QIAamp} \mathrm{Mini}$ kit $($, Qiagen): a extração de DNA foi realizada de acordo com as instruções do fabricante; c) SaltingOut: após o processo de digestão (mencionado anteriormente), foram adicionados $200 \mu \mathrm{l}$ de acetato de amônia $2 \mathrm{M}$ e incubados a $-20^{\circ} \mathrm{C}$ por 5 minutos. Após a centrifugação a $13000 x g$ por 3 minutos, o sobrenadante foi transferido para um novo tubo e $600 \mu \mathrm{l}$ de isopropanol foi adicionado e centrifugado a $16000 x g$ por 15 minutos. O sobrenadante foi descartado e o pellet foi lavado com $200 \mu \mathrm{l}$ de etanol $70 \%$ e centrifugado a $16000 x g$ por 1 minuto. O DNA extraído foi conservado em $80 \mu \mathrm{l}$ de solução TE.

\section{Quantificação e análise}

O DNA foi quantificado no Nanodrop $\AA$ ND-1000 (Thermo Scientific $®$ ) e ajustado para PCR convencional (10ng/ $\mu \mathrm{l}$ para ser utilizado $2 \mu \mathrm{l}$ de DNA em $25 \mu$ l de reação). A amplificação da -actina (136pb) e da amelogenina humana (212pb$218 \mathrm{pb})$ foi realizada no termociclador $A B I 9700$, utilizando água MilliQ como controle negativo e K562 (Promega®, USA) como controle positivo. Os produtos de PCR foram visualizados em gel de agarose a $2 \%$ com Gel Red $\AA$, utilizando pGEM (Promega $\AA$, USA) como padrão de peso molecular através de luz UV pelo equipamento Kodak EDAS. 


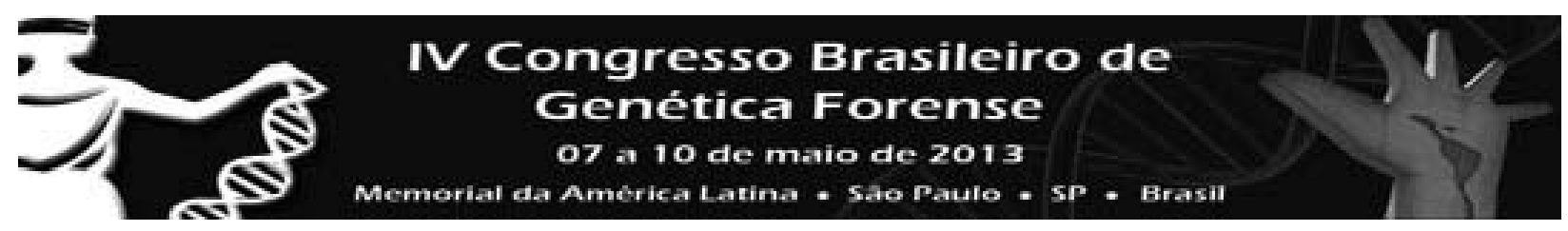

As amostras de DNA extraídas pelo kit comercial que foram amplificadas pelo gene da $\beta$-actina foram submetidas à PCR dos kits AmpFISTR Identifiler® e AmpFISTR MiniFiler ${ }^{\mathrm{TM}}$ (Applied Biosystems, USA), e genotipadas para análise dos fragmentos de $\mathrm{X}$ e $\mathrm{Y}$, pelo gene da amelogenina, bem como dos fragmentos STR, através do sequenciador 3130 Avant Genetic Analyzer (Applied Biosystems, USA).

\section{RESULTADOS}

A Tabela 1 mostra os resultados da concentração de DNA em ng/ $/ \mathrm{l} / \mathrm{cm}^{2}$ (média \pm DP) das amos- tras de baço, fígado e cérebro ( $\mathrm{n}=10$ cada). A tabela apresenta os resultados obtidos dos 3 métodos de extração. O sucesso de amplificação através dos 2 tipos de primers estão expressados em porcentagem. Uma alta quantidade de DNA foi obtida nas amostras extraídas pelo método fenol, nos três grupos de amostras parafinadas (recentes e armazenadas por 1 e 5 anos), quando comparado aos outros 2 métodos de extração. As amostras congeladas foram amplificadas pelos 2 tipos de primers, como controle. Houve uma alta taxa de amplificação para o gene da $\beta$-actina em amostras recentes parafinadas, quando comparadas às amostras armazenadas por 1 e 5 anos.

TABELA 1. DNA extraído de amostras de fígado, baço e cérebro: (a) congeladas; (b) casos recentes FFPE; (c) amostras FFPE armazenadas por 1 ano; e (d) FFPE armazenadas por 5 anos ( $n=10$ cada). Concentração média de DNA $\left(\mathrm{ng} / \mu \mathrm{l} / \mathrm{cm}^{2}\right)$ e taxa de sucesso de amplificação (expresso em porcentagem) dos genes da $\beta$-actina e amelogenina.

\begin{tabular}{|c|c|c|c|c|c|}
\hline & & Congeladas & $\begin{array}{c}\text { Casos } \\
\text { FFPE recentes } \\
\end{array}$ & 1 ano & 5 anos \\
\hline \multirow{9}{*}{ Baço } & Fenol-clorofórmio & $523,5 \pm 88,8$ & $323,9 \pm 135,6$ & $1009,5 \pm 526,6$ & $312,5 \pm 141,7$ \\
\hline & Kit comercial & $117,4 \pm 50,7$ & $21,2 \pm 18,8$ & $14,9 \pm 8,3$ & $34,4 \pm 19,7$ \\
\hline & Salting-Out & $80,5 \pm 52,5$ & $21,2 \pm 20,1$ & $10,5 \pm 6$ & $19,2 \pm 24,1$ \\
\hline & $\beta$-actina $(+)$ Fenol & $100 \%$ & $100 \%$ & $60 \%$ & $50 \%$ \\
\hline & $\beta$-actina $(+)$ Kit & $100 \%$ & $100 \%$ & $50 \%$ & $50 \%$ \\
\hline & $\beta$-actina $(+)$ Salting-Out & $100 \%$ & $100 \%$ & $60 \%$ & $100 \%$ \\
\hline & Amelogenina (+) Fenol & $100 \%$ & - & $0 \%$ & - \\
\hline & Amelogenina (+) Kit & $100 \%$ & $100 \%$ & $0 \%$ & - \\
\hline & Amelogenina (+) Salting-Out & $100 \%$ & - & - & - \\
\hline \multirow{9}{*}{ Fígado } & Fenol-clorofórmio & $1522,7 \pm 693,7$ & $313,2 \pm 152,4$ & $1045,6 \pm 572,4$ & $274,4 \pm 127,8$ \\
\hline & Kit comercial & $80,7 \pm 61,8$ & $27,5 \pm 15,8$ & $14 \pm 10,2$ & $24,3 \pm 21,8$ \\
\hline & Salting-Out & $70,5 \pm 50,2$ & $11,7 \pm 7,1$ & $16,2 \pm 11,8$ & $7,6 \pm 4,2$ \\
\hline & $\beta$-actina $(+)$ Fenol & $100 \%$ & $90 \%$ & $70 \%$ & $40 \%$ \\
\hline & $\beta$-actina $(+)$ Kit & $100 \%$ & $100 \%$ & $60 \%$ & $60 \%$ \\
\hline & $\beta$-actina $(+)$ Salting-Out & $100 \%$ & $100 \%$ & $70 \%$ & $100 \%$ \\
\hline & Amelogenina (+) Fenol & $100 \%$ & - & $0 \%$ & - \\
\hline & Amelogenina (+) Kit & $100 \%$ & $100 \%$ & $0 \%$ & - \\
\hline & Amelogenina (+) Salting-Out & $100 \%$ & - & - & - \\
\hline \multirow{9}{*}{ Cérebro } & Fenol-clorofórmio & $524,8 \pm 205,9$ & $182,6 \pm 125,7$ & $335,2 \pm 115,4$ & $157 \pm 69,3$ \\
\hline & Kit comercial & $10,3 \pm 3,9$ & $11 \pm 7$ & $7,2 \pm 4,3$ & $14,5 \pm 8,3$ \\
\hline & Salting-Out & $148,6 \pm 89,6$ & $6,3 \pm 3,1$ & $6,5 \pm 4,4$ & $7,9 \pm 6,3$ \\
\hline & $\beta$-actina (+) Fenol & $100 \%$ & $70 \%$ & $70 \%$ & $50 \%$ \\
\hline & $\beta$-actina $(+)$ Kit & $100 \%$ & $100 \%$ & $20 \%$ & $40 \%$ \\
\hline & $\beta$-actina $(+)$ Salting-Out & $100 \%$ & $100 \%$ & $80 \%$ & $100 \%$ \\
\hline & Amelogenina (+) Fenol & $100 \%$ & - & $0 \%$ & - \\
\hline & Amelogenina $(+)$ Kit & $100 \%$ & $100 \%$ & $0 \%$ & - \\
\hline & Amelogenina (+) Salting-Out & $100 \%$ & - & - & - \\
\hline
\end{tabular}

As amostras extraídas pelo SaltingOut apresentaram um menor grau de pureza, heterogeneidade e variação, quando comparado às extrações com fenol e kit. A extração pelo kit ren-deu 


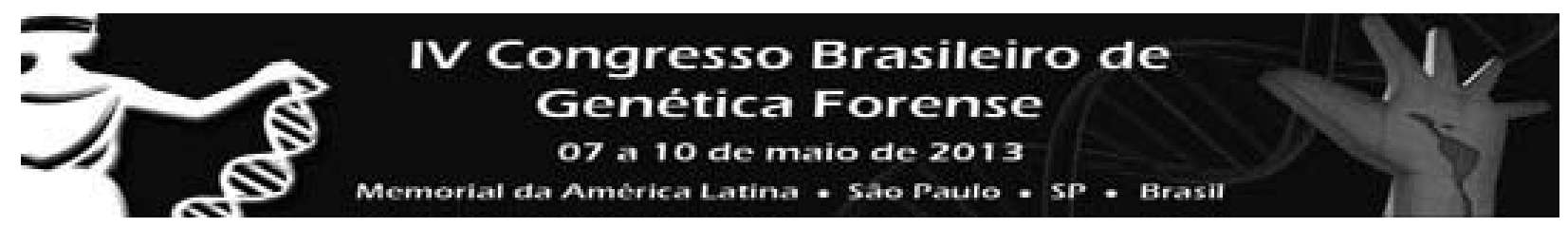

um maior grau de pureza (leitura 260/280), embora, neidade entre as amostras parafinadas recentes e no método pelo fenol, houve uma maior homoge- armazenadas por 1 e 5 anos (Gráficos 1 a 3).

DNA extraído de cérebro

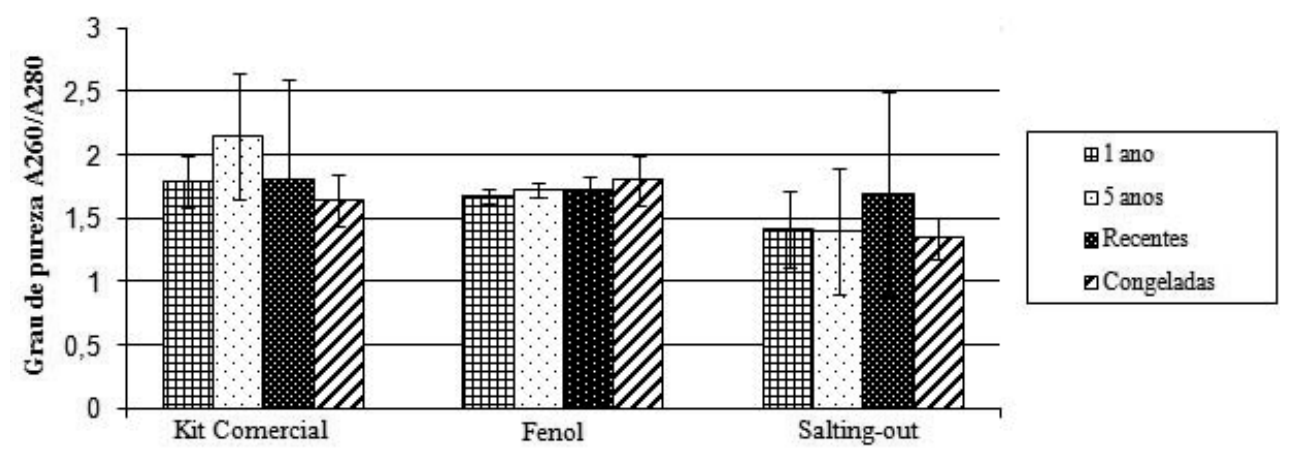

GRÁFICO 1. Grau de pureza (A260/A280) do DNA extraído de amostras de cérebro congeladas, parafinadas recentes e ar mazenadas por 1 e 5 anos, utilizando 3 métodos de extração: kit comercial, fenol e Salting-out

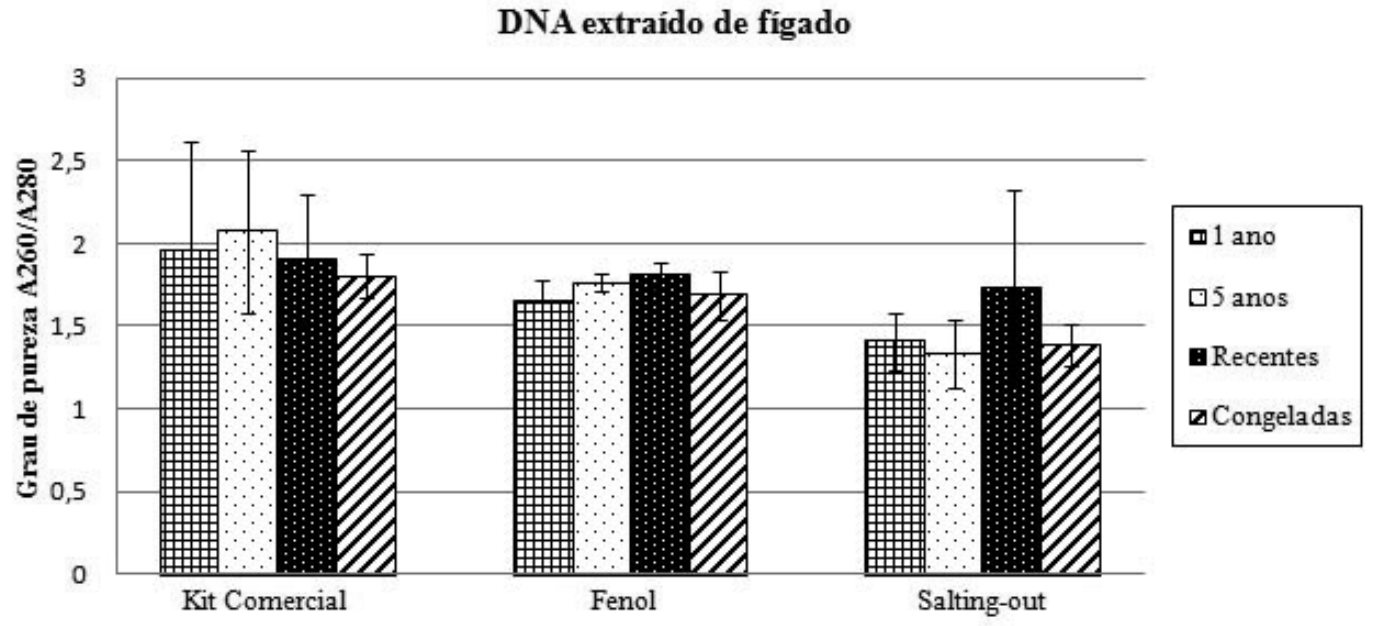

GRÁFICO 2. Grau de pureza (A260/A280) do DNA extraído de amostras de fígado congeladas, parafinadas recentes e ar mazenadas por 1 e 5 anos, utilizando 3 métodos de extração: kit comercial, fenol e Salting-out

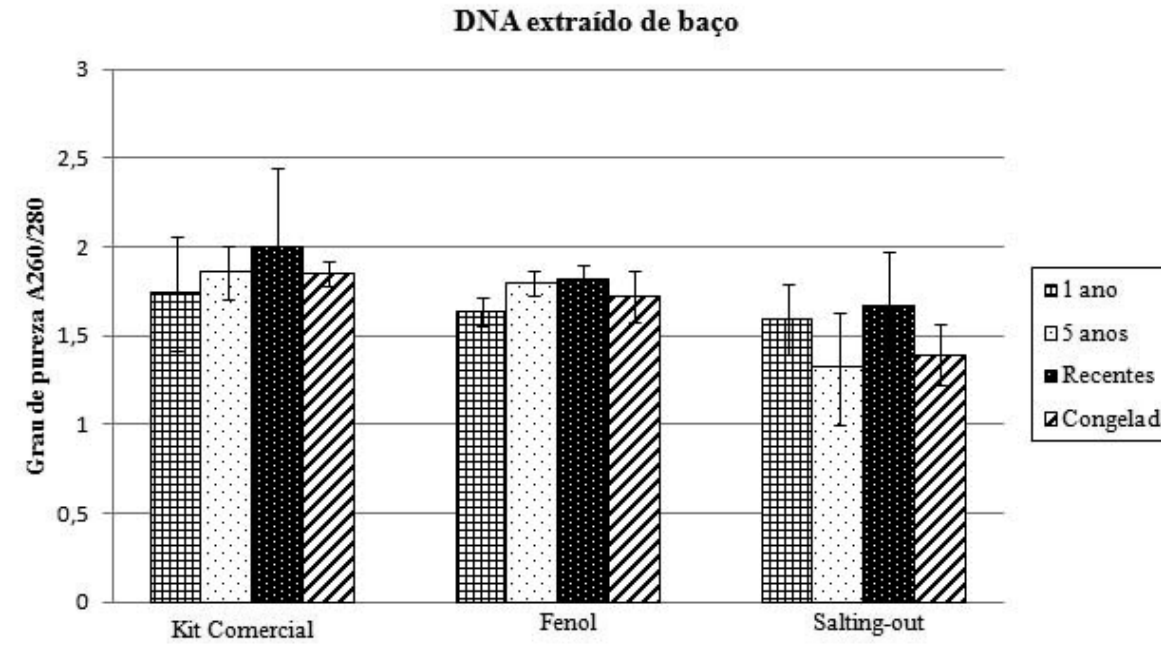

GRÁFICO 3. Grau de pureza (A260/A280) do DNA extraído de amostras de baço congeladas, parafinadas recentes e arma zenadas por 1 e 5 anos, utilizando 3 métodos de extração: kit comercial, fenol e Salting-out 


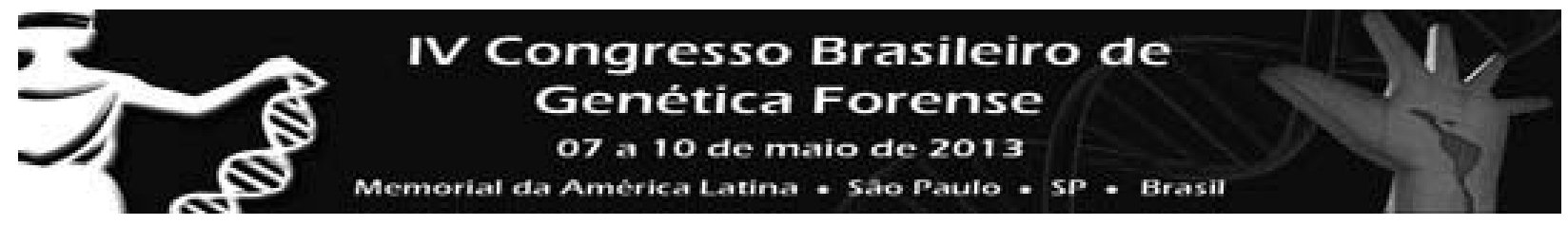

O gene da amelogenina foi amplificado em todas as amostras através do STR. A região de análise do gene da amelogenina tem o comprimento de 106-112pb (menor que a região visualizada no gel de agarose, de 212-218pb). Entretanto, apenas em algumas amostras parafinadas, a análise dos marcadores foi possível, com picos maiores que 50 RFU, assim como em outros loci que possuíam comprimento maior que 200pb (dados não mostrados).

\section{DISCUSSÃO}

Os melhores resultados de amplificação do gene da $\beta$-actina foram observados nas amostras recentes, mostrando uma pequena variação entre os tecidos, especialmente nas amostras de cérebro extraídas com fenol. Os períodos restantes, de 1 e 5 anos de armazenamento, mostraram um decréscimo gradual na amplificação utilizando o método de fenol, indicando que, embora este método consiga extrair grandes quantidades de DNA, algumas regiões afetadas podem não ser amplificadas para uso em biologia molecular.

O método de extração Salting-Out mostrou variações nos resultados de amplificação em relação às extrações com fenol e kit nas amostras armazenadas por 1 e 5 anos. As amostras armazenadas por 1 ano tiveram piores resultados. Esse dado é contrario ao esperado, uma vez que o mais lógico seria melhores resultados nessas amostras em relação as de 5 anos. Por outro lado, também observamos nos gráficos 1-3, níveis de pureza encontrados nas amostras armazenadas por 1 ano inferiores em relação às armazenadas por 5 anos. Uma das explicações possíveis podem ser variações na qualidade dos reagentes utilizados no processamento das amostras. No geral, os dados de 5 anos em relação aos casos recentes mostraram-se consistentemente piores na obtenção de reações positivas de PCR. Nossas amostras obtidas de necropsias não são uniformes em relação ao tempo de fixação e ao processo de inclusão em parafina, o que poderia explicar alguns de nossos resultados. Em nosso estudo, também, o processo de inclusão das amostras pode ter afetado os resultados. O tempo de armazenamento dos blocos pode influenciar na qualidade do DNA extraído, porém a qualidade dos materiais utilizados no processamento de fixação dos tecidos e dos blocos de parafina pode interferir na qualidade do DNA obtido.

Enquanto a extração com fenol apresentou melhores resultados quanto ao grau de pureza (valores de 1.8 para as leituras de A260/A280) e maior concentração de DNA, a extração com kit comercial mostrou maiores intensidades de banda no gel de agarose. Neste tipo de extração, o processo de purificação resulta em um melhor material pós-PCR a ser analisado, por conta do processo de filtragem presente no kit.

Diversos protocolos de extração têm sido descritos para obtenção de um DNA de melhor qualidade em amostras arquivadas ${ }^{8,}$ 9, ${ }^{15}$. As variações nos protocolos focam em diferentes etapas do processamento das amostras, como a desparafinização, tempo, digestão com proteinase $\mathrm{K}$, extração de DNA e métodos de purificação.

O processo de fixação e inclusão em parafina parece "amarrar" o DNA, inibindo as reações de PCR. De acordo com diversos autores, a etapa mais crítica para se obter um DNA íntegro é na fixação em formalina ${ }^{10,15}$. Entretanto, em nosso estudo e de acordo com Gillio Tos et al $2007^{11}$, o processo de inclusão em parafina mostrou uma importante ação na obtenção de um DNA amplificável para análise.

O kit de STR Identifiler $囚$ é rotineiramente utilizado para estudos de genética forense e, mais recentemente, os mini-STR têm sido adotados para análise de perfis genéticos para identificação humana ${ }^{14}$. Nestes kits, o primer da amelogenina (106-112pb) está incluído em uma reação única e multiplex de PCR. Os resultados incompletos dos perfis de STR corroboram com outros autores ${ }^{13} \mathrm{em}$ relação à fragmentação e não amplificação.

Um cuidado especial deve ser tomado ao comparar a qualidade do DNA extraído de material de necropsia FFPE com biópsias. Muitas vezes, materiais de autópsias permanecem mais tempo no fixador em relação aos espécimes cirúrgicos. No entanto, é intuitivo que os resultados do presente estudo sobre os diferentes métodos de extração e os fatores que influenciam a qualidade do DNA também possam ser encontrados ao lidar com biópsias.

Este é o primeiro trabalho que avaliou tecidos não tumorais FFPE com três metodos de extração de DNA mais comuns, avaliando PCR para identificação de sexo e STR de até $400 \mathrm{pb}$, mostrando que embora alguns tecidos FFPE contenham grandes quantidades de DNA e com alto grau de pureza, os efeitos da formalina e os reagentes usados no processo de parafinização impedem a amplificação efetiva pela PCR dos fragmentos alvos.

Concluindo, o método que empregou o kit comercial apresentou resultados reprodutíveis 


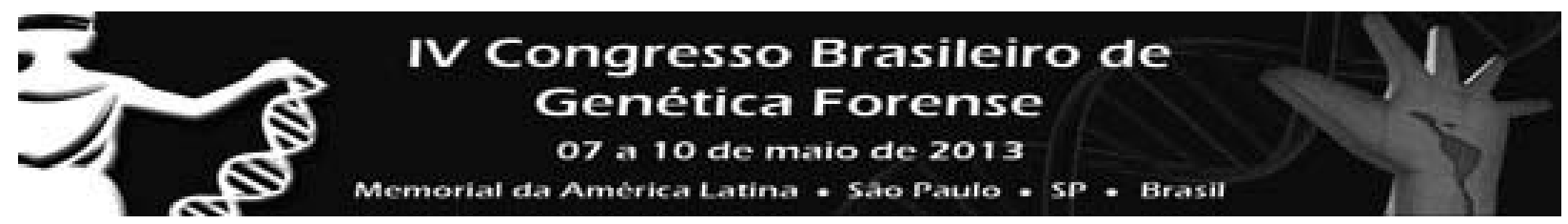

e mais consistentes na amplificação por PCR do gene da $\beta$-actina e amelogenina. Este estudo fornece uma compreensão dos desafios envolvendo amostras parafinadas para análises de biologia molecular, principalmente para futuros estudos em amostras de tecidos FFPE.

\section{REFERÊNCIAS}

1. Alvarez-Lafuente $R$, Aguilera $B$, Suárez-Mier MA et al. Detection of human herpesvirus-6, Epstein-Barr virus and cytomegalovirus in formalin-fixed tissues from sudden infant death: a study with quantitative real-time PCR. Forensic Sci Int. 2008; 178: 106-11.

2. Lassalle $\mathrm{S}$, Hofman V, Ilie $\mathrm{M}$, et al. Assessment of morphology, antigenicity, and nucleic acid integrity for diagnostic thyroid pathology using formalin substitutive fixatives. Thyroid. 2009; 19: 1239-48.

3. Budimlija Z, Lu C, Axler-DiPerte G, et al. Malignant tumours and forensics - dilemmas and proposals, Croat Med J. 2009; 50: 218-27.

4. Ananian V, Tozzo P, Ponzano E, et al. Tumoural specimens for forensic purposes: comparison of genetic alterations in frozen and formalin-fixed paraffin-embedded tissues. Int J Legal Med. 2010; 125: 327-32.

5. Banaschak S, Du Chesne A, Brinkmann B. Multiple interchanging of tissue samples in cases of breast cancer. Forensic Sci Int. 2000; 113: 3-7.

6. Doran GH, Dickel DN, Ballinger Jr. WE et al Anatomical, cellular and molecular analysis of $8000-y r-$ old human brain tissue from the Windover archaeological site. Nature. 1986; 323: 803-6.

7. Crisan D, Cadoff EM, Mattson JC, et al. Polymerase chain reaction: amplification of DNA from fixed tissue. Clin Biochem. 1990; 23: 489-95.

8. Ferrer I, Armstrong J, Capellari S, et al. Effects of formalin fixation, paraffin embedding, and time of storage on DNA preservation in brain tissue: a Brain Net Europe study. Brain Pathol. 2007; 17: 297-303.

9. Duval K, Aubin RA, Elliot J, et al. Optimized manual and automated recovery of amplifiable DNA from tissues preserved in buffered formalin and alcoholbased fixative. Forensic Sci Int. 2010; 4: 80-8.

10. Bonin S, Petrera F, Niccolini B, et al. PCR analysis in archival postmortem tissues. J Clin Pathol. 2003; 56: 184-186.

11. Gillio-Tos A, De Marco L, Fiano V, et al. Efficient DNA extraction from 25- year-old paraffin-embedded tissues: study of 365 samples. Pathology. 2007; 39: 345-48.

12. Coura R, Prolla JC, Meurer L, et al. An alternative protocol for DNA extraction from formalin fixed and paraffin wax embedded tissue. J Clin Pathol. 2005; 58: 894-5.

13. Casale V, Oneda R, Lavezzi AM, et al. Optimisation of postmortem tissue preservation and alternative protocol for serotonin transporter gene polymorphisms amplification in SIDS and SIUD cases. Exp Mol Pathol. 2010; 88: 202-5.

14. Hill CR, Kline MC, Mulero JJ, Lagacé RE, Chang CW, Hennessy LK, Butler JM. Concordance study between the AmpFISTR MiniFiler PCR amplification kit and conventional STR typing kits. J Forensic Sci. 2007; 52: 870-3.

15. Greer CE, Lund JK, Manos MM. PCR amplification from paraffin-embedded tissues: recommendations on fixatives for long-term storage and prospective studies. PCR Methods Appl. 1991; 1: 46-50. 